\title{
STUDI MODIFIKASI JALUR METABOLIK SACCHAROMYCES CEREVISIAE DALAM PROSES PEMBUATAN ETANOL
}

\section{Modification Study of Metabolic Pathways of Saccharomyces cerevisiae in Ethanol Production}

\author{
Mayang Gitta Pawitra \\ Fakultas Teknik, Universitas Pamulang, Jalan Witana Harja no.18B, Pamulang Barat \\ Email: mayang_gitta@yahoo.com
}

\begin{abstract}
ABSTRAK
Proses fermentasi etanol dari lignocellulose diyakini sebagai alternatif produksi biofuel yang ramah lingkungan. Metode ini umum digunakan, namun diperlukan inovasi lain untuk menghasilkan yield etanol yang tinggi. Salah satu yang ditinjau dalam artikel ini adalah memodifikasi jalur metabolik Saccharomyces cerevisiae agar dapat memfermentasi xylose dan juga glukosa. Untuk mengkondisikan agar Saccharomyces cerevisiae dapat menghasilkan etanol dari xylose, harus dilakukan modifikasi menggunakan bantuan mikroba, Pichia stiptis. Pichia stipitis memiliki kemampuan untuk mengkodekan gen yang berfungsi untuk mengkonversi xylose ke xylulose-5-p. xylulose-5-p melalui jalur phosfat pentose disintesa menjadi etanol. Metode penggabungan S.Cerevisiae dan P.stipitis menghasilkan produk etanol dengan yield yang tinggi.
\end{abstract}

Kata kunci:etanol, fermentasi, xylose, Saccharomyces cerevisiae, Pischia stiptis

\begin{abstract}
Ethanol fermentation from lignocellulose is believed to be an environmental- friendly innovation for an alternative biofuel production. This method is commonly used although a little modification needs to be applied in order to achieve higher ethanol yield. One of the modification proposed in this article is by modifying the metabolic pathways of S.cerevisiae in a way that this glucose fermenting yeast is able to be situated to ferment both xylose and glucose hence resulting higher ethanol production. In order to condition Saccharomyces cerevisiae to produce ethanol from xylose, the metabolic pathways has to be engineered with the help of a filamentous fungi, Pichia stiptis. Pichia stipitis has the capability to encode the gene of XYL1 and XYL2 which functions to convert xylose into xylulose-5-p. Xylulose-5-p through the pentose phosphate pathway is turned to produce fructose 6-p (Hahn, 2002). The production of fructose 6-p is a connection point, leading to glycolytic pathways and ethanol fermentation. The combination of S.Cerevisiae dan P.stipitis is believed increase the amount of ethanol produced.
\end{abstract}

Keywords : ethanol, fermentation, xylose, Saccharomyces cerevisiae, Pischia stiptis

\section{PENDAHULUAN}

Krisis energi saat ini mendorong peneliti untuk mengembangkan energi alternatif dari sumber terbarukan. Bioethanol, sebagai salah satu solusi untuk energi terbarukan, biasanya terbuat dari fermentasi mikroba berbasis bahan baku seperti jagung, singkong [1] dan sering digunakan sebagai aditif untuk meningkatkan emisi kendaraan. Etanol juga dapat disintesa dari lignocellulose dan proses ini diyakini sebagai alternatif produksi biofuel yang ramah lingkungan.

Selulosa, hemiselulosa dan lignin sebagian besar mengandung hydrolyzates dari biomassa lignocellulostic. Seperti tertera dalam gambar 1. $35.51 \%$ lignocellulose terdiri dari selulosa dalam bentuk hexoses [2]. Pada hemiselulosa, ditemukan 19.34\% lignocellulose dalam dua 


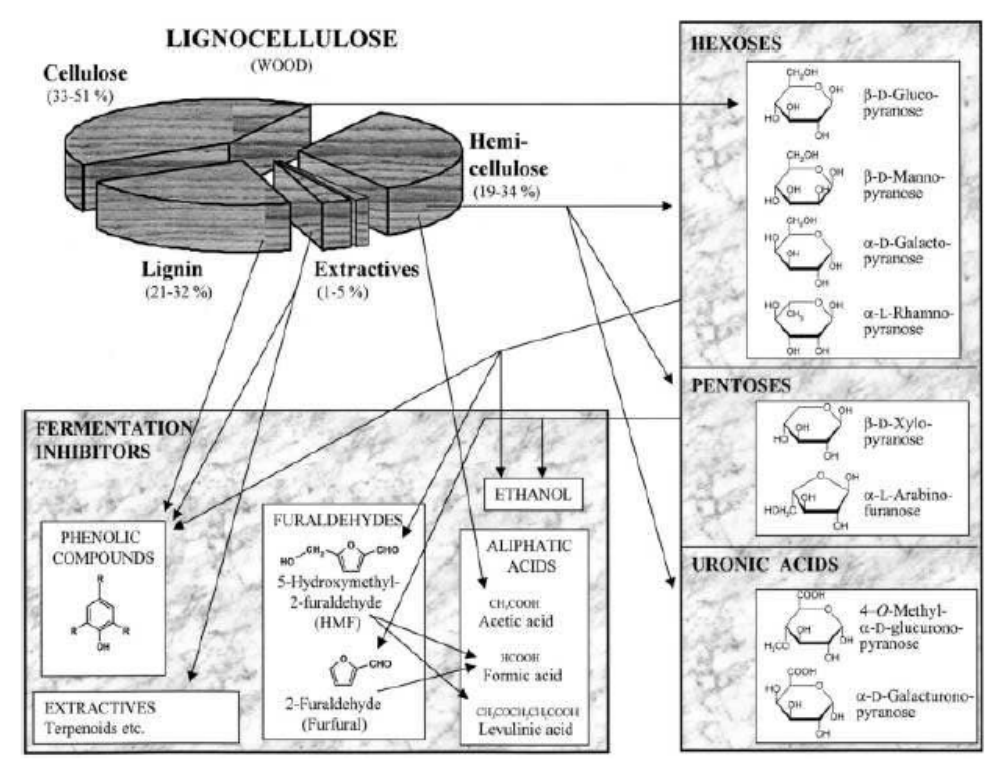

Gambar 1. Inhibitor fermentasi pada lignoselulosa

bentuk yaitu hexoses dan pentoses [1]. Hexoses yang dihasilkan dari proses pemecahan selulosa dengan menggunakan mikroba dalam kondisi asam dipercaya dapat menghasilkan pentose [3]. Pentosa merupakan bahan baku utama untuk produksi xylose dan arabinose [4]. Oleh karena itu, untuk mengoptimalkan konversi biomass menjadi biofuel dan menghasilkan yield etanol yang tinggi, diperlukan suatu organisme yang mampu memanfaatkan xylose serta glukosa. Dewasa ini, Saccharomyces cerevisiae umum digunakan untuk produksi bioethanol dalam skala besar [5]. Ketahanan dan toleransi yang lebih tinggi dari Cerevisiae sebagai inhibitor juga merupakan alasan lain untuk ragi ini digunakan guna mencapai proses fermentasi hexoses dan pentoses yang efisien [6].

Namun, karena keterbatasannya, Sacharomyces hanya mampu memfermentasi glukosa, tidak mampu memfermentasi xylose secara langsung [7]. Oleh karena itu, perlu adanya modifikasi Saccharomyces cerevisiae agar dapat memfermentasi xylose dan glukosa dan menghasilkan konversi etanol yang lebih tinggi. Mekanisme modifikasi Saccharomyces cerevisiae dan optimasi proses akan dibahas dalam tulisan ini.

\section{PEMBAHASAN}

Jalur Metabolisme Saccharomyces cerevisiae untuk menghasilkan etanol

Saccharomyces cerevisiae tidak dapat memfermentasi xylose karena keterbatasannya mengkonversi xylose ke xylulose-5-p [7]. Untuk mengkondisikan agar Saccharomyces cerevisiae dapat menghasilkan etanol dari xylose, harus dilakukan modifikasi jalur metabolik menggunakan bantuan mikroba, Pichia stiptis. Pada gambar 2, terlihat bahwa Pichia stipitis memiliki kemampuan untuk mengkodekan gen XYL1 dan XYL2 yang berfungsi untuk mengkonversi xylose ke xylulose-5-p. Gen XYL1 dan XYL2 berperan penting untuk asimilasi xylose pada Saccharomyces cerevisiae [8]. Berdasarkan penelitian yang dilakukan oleh [7], metode penggabungan S.Cerevisiae dan P.stipitis 


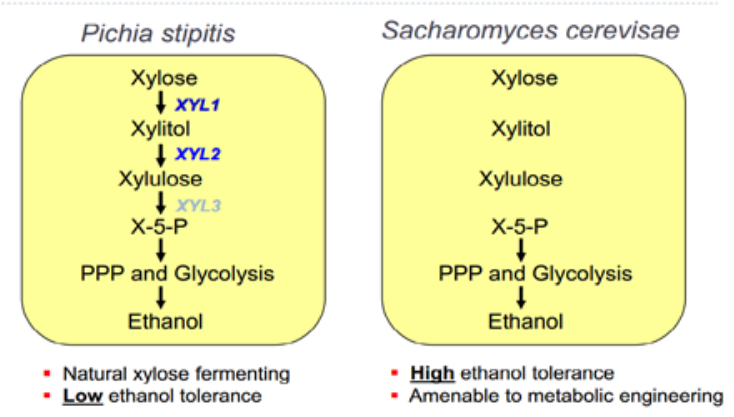

Gambar 2. Jalur metabolik fermentasi xylulose pada Saccharomyces cerevisiae

menghasilkan produk etanol dengan konsentrasi 50 gl-1 dan yield 0.5g.g - $^{-1}$ [1]

Proses metabolise xylulose oleh Saccharomyces cerevisiae terjadi melalui jalur fosfat pentosa (PPP). Seperti yang tertera dalam gambar 2, metabolisme xylosa dimulai dengan masuknya XYL1 gen sebagai pengkode untuk proses reduksi dari xylose menjadi xylitol melalui proses reduksi xylose (XR) [10]. Berlangsungnya proses XR's bergantung pada NADH dan NADPH [11]. NADPH didapat dari reaksi di jalur pentosa dan dapat pula diperoleh dari proses pembentukan asetat dari asetaldehid [12].

Setelah XYL1, gen XYL2 mengkode untuk pembentukan xylitol dehidrogenase. Xylitol dehidrogenase (XDH) memiliki fungsi untuk mengkonversi xylitol ke xylose [13]. Tidak seperti reduktase xylose, enzim ini menggunakan NAD untuk mengubah reaksi dan menghasilkan NADH [11]. Enzim xylokinase digunakan pada proses sintesa xylulose menjadi xylulose 5-p dengan menggunakan ATP sebagai on-off switch dalam reaksi tersebut. ATP juga digunakan untuk memberikan energi untuk melalui keseluruhan proses tersebut [6]. Setelah melewati proses ini, xylulose-5-fosfat diproses melalui jalur pentosa fosfat.

Dalam jalur pentose fosfat sebagaimana tergambar pada gambar 5, dengan bantuan gen transketolase (TKL) dan transaldolase (TAL), xylulose-5-fosfat berproses untuk menghasilkan fruktosa 6-p [3]. Produksi fruktosa 6-p merupakan titik penghubung yang mengarah ke jalur glycolytic dan fermentasi etanol [10].

\section{Penggunaan enzim untuk meningkatkan yield etanol}

Pada praktek menggunakan

Saccharomyces cerevisiae, keseimbangan redoks antara NAD / NADH dan NADP / NADPH menjadi sangat penting dalam memelihara homeostasis sel [10] NADH digunakan dalam proses oksidatif sedangkan NADPH dominan dalam proses reduktif [10].

Agar sel dapat berfungsi baik, rasio NAD / NADH perlu dijaga dikisaran 1000 agar proses oksidasi dapat berlangsung sementara di waktu yang sama harus dipertahankan pada rasio NADP / NADPH 0.01 untuk proses reduksi [14]. NAD / $\mathrm{NADH}$ dan NADP / NADPH harus dijaga pada kondisi seimbang selama proses berlangsung [15].

XR bergantung pada NADH dan NADPH sedangkan XDH bergantung pada NAD. Rekombinan Saccharomyces cerevisiae menghasilkan NADPH selama proses fermentasi xylose ke etanol sedangkan dalam NADH dihasilkan dari produksi xylitol oleh xylose reduktas [14]. Pada reaksi $\mathrm{XR}$, jika tidak terdapat NADH dalam jumlah yang mencukupi maka sedikit pula NAD+ yang tersedia untuk reaksi XDH. Hal tersebut menyebabkan sedikitnya xylitol yang di produksi dan berdampak pada penurunan yield etanol [15]. 


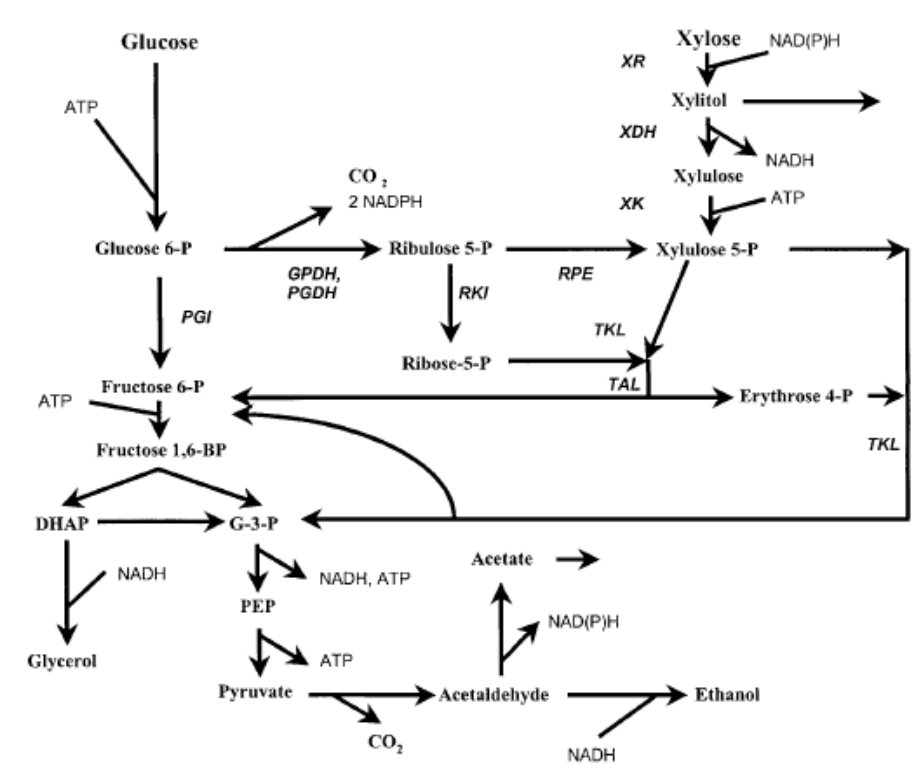

Gambar 3. Strategi agar yeast dapat memfermentasi glukosa dan xylose

Untuk mengatasi masalah ini, XR dimodifikasi agar memilih NADH sebagai kofaktor serta XDH diarahkan menggunakan NADP+ sebagai kofaktor. Dari percobaan tersebut didapat hasil xylitol yang lebih rendah dengan yield etanol yang lebih tinggi [3].

\section{KESIMPULAN}

Saccharomyces cerevisiae telah banyak digunakan sebagai ragi dalam fermentasi namun tidak dapat memfermentasi xylose. Alternatifnya adalah dengan menggabungkan S.cerevisiae dengan gen dari Pichia stiptis dan mengubah jalur metabolik S.cerevisiae melalui jalur pentose. Opsi tersebut ditawarkan agar dapat mensintesa xylose dan menghasilkan konversi etanol yang tinggi. Gen XYL1 dan XYL2 mengkode proses reduktase xylose dan dehidrogenasi xylitol. Enzim ini membantu untuk mengarahkan reaksi Saccharomyces Cerevisiae agar menghasilkan etanol sebagai produk akhir dari sintesa xylose. Meskipun demikian, fermentasi xylose memiliki beberapa kekurangan seperti yield etanol yang
rendah.Hal ini disebabkan oleh akumulasi xylitol terjadi selama proses.

Akumulasi xylitol terjadi karena ketidakseimbangan redoks dalam proses fermentasi. Untuk mengatasi masalah ini, berikut beberapa strategi telah dikembangkan seperti mengubah preferensi XR dan XDH sebagai kofaktor, menerapkan siklus transhydrogenase dan mengurangi fluks melalui PPP untuk mengurangi produksi NADPH. Namun, penelitian lanjutan masih perlu dilakukan untuk mendapatkan kondisi optimal guna meningkatkan produksi etanol dan mempercepat laju produksi.

\section{DAFTAR PUSTAKA}

[1] Rosenberg, M., D. Gutnick., E. Rosenberg. (1980) Adherence of Bacteria to Hydrocarbons: A Simple Method for Measuring Cell-Surface Hydrophobicity. FEMS Microbiology Letters, 9(1): 29-33, https://doi.org/10.1111/j.15746968.1980.tb05599.x.

[2] Aristidou, A., M. Penttila. 2001. Metabolic engineering applications to 
renewable resource utilization. Curr. Opin. Biotechnol., 11, 478-483. https://www.ncbi.nlm.nih.gov/pubmed/ 10753763.

[3] Anderlund, P. Rådström, and B. H. Hägerdal, (2001) Expression of bifunctional enzymes with Xylose Reduc-tase and Xylitol Dehydrogenase activity in Saccharomy-ces cerevisiae alters product formation during Xylose fermentation. $\quad[\mathrm{J}]$ Metabolic Engineering, 3(3), 226-235.

[4] Carroll A, Somerville C (2009) Cellulosic biofuels. Annu Rev Plant Biol 60:165-182.

[5] Zaldivar J, Nielsen J, Olsson L: Fuel ethanol production from lignocellulose: a challenge for metabolic engineering and process integration. Appl Microbiol Biotechnol 2001, 56:17-34.

[6] Lau MW, Gunawan C, Balan V, Dale $\mathrm{BE}$ : Comparing the fermentation performance of Escherichia coli KO11, Saccharomyces cerevisiae 424A (LNHST) and Zymomonas mobilis AX101 for cellulosic ethanol production. Biotechnol Biofuels 2010, 3:11.

[7] Tsao GT, Ladisch MR,Voloch M, Bienkowski P (1982) Process Biochem $17: 34$

[8] Kern Alexander, Tilley Emma, Hunter Iain, Legisa Matic, Glieder Anton. Engineering primary metabolic pathways of industrial micro-organism. Journal of Biotechnology 129: 6-29.

[9] Kolot FB (1980) Process Biochem 15:2

[10] Hahn-Hägerdal B1, Wahlbom CF, Gárdonyi M, van Zyl WH, Cordero Otero RR, Jönsson LJ. (2001). Metabolic engineering of Saccharomyces cerevisiae for xylose utilization. Adv Biochem Eng
Biotechnol., 73: 53-84, https://www.ncbi.nlm.nih.gov/pubmed/118 16812.

[11] Suk Jin Ha, Galazzka, Jonathan M, Jin Ho Seo, Soo Rin Kim. (2010) Engineered S.Cerevisiae capable of simultaneous cellobiose and xylose fermentation. Department of Food Science and Human Nutrition. University of Illinois.

[12] Parachin NS, Bengtsson O, Hahn Hagerdal B, Gorwa MF. 2010. The deletion of YLR042c improves ethanolic xylose fermentation by recombinant Saccharomyces cerevisiae. PubMed(9):741-751.

[13] Bicho PA, Runnals PL, Cunningham JD, Lee H (1988) Appl Environ Microbiol 54:50

[14] Voet, D. and Voet, J. G. (1995). In "Biochemistry". John Wiley \& Sons, Inc.

[15] Demeke et al.(2013). Development of a D-xylose fermenting and inhibitor tolerant industrial Saccharomyces cerevisiae strain with high performance in lignocellulose hydrolysates using metabolic and evolutionary engineering. Biotechnology for Biofuels. 6:89, https://doi.org/10.1186/1754-6834-6$\underline{89}$. 